\title{
Drivers of variability in water use of native and non-native urban trees in the greater Los Angeles area
}

\author{
Heather R. McCarthy • Diane E. Pataki
}

Published online: 23 April 2010

(C) The Author(s) 2010. This article is published with open access at Springerlink.com

\begin{abstract}
Trees in urban ecosystems are valued for shade and cooling effects, reduction of $\mathrm{CO}_{2}$ emissions and pollution, and aesthetics. However, in arid and semi-arid regions, urban trees must be maintained through supplemental irrigation, in competition with other water needs. Currently, a comprehensive understanding of the factors which influence water use of urban tree species is lacking. In order to study the drivers of whole tree water use of two common species in the Los Angeles Basin urban forest, four sites in Los Angeles and Orange County were instrumented with sap flow and meteorological sensors. These sites allowed comparisons of the water use of a native riparian (Platanus racemosa Nutt.; California sycamore) and non-native (Pinus canariensis C. Sm.; Canary Island pine) Mediterranean species, as well as the spatial variability in water use under different environmental and management conditions. We found higher rates of sapflux $\left(J_{O}\right)$ in native California sycamore as compared to non-native Canary Island pine. Within each species, we found considerable site-to-site variability in the magnitude and seasonality of $J_{O}$. For Canary Island pine, the majority of inter-site variability derived from differences in water availability: response to vapor pressure deficit was similar during a period without water limitations. In contrast, California sycamore did not appear to experience water limitation at any site; however, there was considerable spatial variability in water use, potentially linked to differences in nutrient availability. Whole tree transpiration $(E)$ was similar for the two species when water was not limiting, but Canary Island pine was able to withstand unirrigated conditions with a very low $E$. These results add to the currently small pool of data on urban tree water use and ecophysiology, and contribute to establishing a more quantitative understanding of urban tree function.
\end{abstract}

Keywords Managed landscapes · Plant hydraulics · Sapflux · Urban ecology · Water stress

H. R. McCarthy $(\bowtie) \cdot$ D. E. Pataki

Department of Earth System Science, University of California, Irvine, CA 92697-3100, USA

e-mail: heather.mccarthy@uci.edu

D. E. Pataki

Department of Ecology and Evolutionary Biology, University of California, Irvine, CA 92697, USA 


\section{Introduction}

Trees in urban ecosystems are valued for shade and reductions in air temperature, mitigation of $\mathrm{CO}_{2}$ emissions and pollution, and aesthetics, among other benefits (e.g. Akbari 2002; Grimmond et al. 1996; McPherson et al. 2005; Nowak and Dwyer 2007; Pataki et al. 2006). In order to capitalize on the beneficial qualities of trees, many municipalities and urban residents are engaged in programs to increase urban tree cover. For example, the city of Los Angeles has committed to a major tree planting program (http://www.milliontreesla.org). However, in arid regions which are not naturally forested, urban trees must be irrigated, and this allocation of water may come at the expense of other uses. Assessments of outdoor water use across California (Gleick et al. 2003), in Phoenix, Arizona (Balling et al. 2008) and College Station, Texas (White et al. 2007) have shown that not only is $30-75 \%$ of residential water use expended on outdoor landscapes, irrigation is frequently in excess of estimated plant demand (White et al. 2007). Thus, there is a need to understand the factors which influence the magnitude and seasonality of water use of different urban tree species. Recently, several city-scale models have been developed to quantify some aspects of urban tree function, most commonly carbon and pollutant uptake, and shading (McPherson et al. 2005; Nowak and Crane 2000; Nowak et al. 2008). However, water use of urban trees has seldom been incorporated in models of the costs and benefits of urban trees (but see Wang et al. 2008).

Because the physiology and morphology of urban trees may differ substantially from natural forests, it is difficult to obtain quantitative estimates of urban tree water use without direct measurements. Urban trees clearly face different growing conditions than natural trees. On one hand, urban trees may experience some alleviation of factors that commonly limit growth through irrigation and fertilization (Pickett and Cadenasso 2009), leading to growth enhancements relative to trees in natural forests (e.g. Rhoades and Stipes 1999). However, urban trees may also face stresses such as increased pollution, vandalism, restricted rooting area, and increased evaporative demand driven by non-native environments and urban heat island effects (Clark and Kjelgren 1990; Whitlow and Bassuk 1987). Furthermore, in areas where urban trees are not regularly irrigated and impervious surfaces reduce infiltration of precipitation, trees may face water stress and reduced growth (Clark and Kjelgren 1990; Close et al. 1996a; Close et al. 1996b; Kjelgren and Clark 1993). It is generally predicted that trees in urban sites will have higher water loss than trees in natural forests due to increased atmospheric demand. However, a study of sweetgum in Seattle found lower transpiration in isolated trees in an urban "plaza" than in a nearby park, despite higher vapor pressure deficit at the plaza site (Kjelgren and Clark 1993). This water savings was attributed to lower stomatal conductance and canopy leaf area at the plaza site (Kjelgren and Clark 1993). Additionally, urban conditions could influence water use through changes in stem hydraulic conductivity. In particular, prolonged water stress can result in xylem which is more stress resistant and less conductive (e.g. Alder et al. 1996; Ewers et al. 2000; Ladjal et al. 2005). As there have been few studies of transpiration in mature urban trees, there is currently insufficient data to generalize the physiological responses of trees to the complex urban environment.

Another difficulty in assessing spatial variability in urban tree water use is the widely recognized heterogeneity of urban environments (e.g. Cadenasso et al. 2007; Grimm et al. 2000; Pickett et al. 2001; Pickett and Cadenasso 2009). Numerous factors contribute to spatial heterogeneity in urban systems, primarily driven by human choice and decisionmaking, both by individuals and collectively in institutions. This results in a landscape with significant variability in water and nutrient inputs, infiltration capacity (water availability), 
microclimate (based on proportion of vegetation to artificial surfaces) and biotic inputs and composition (Grimm et al. 2000; Pataki et al. 2006; Pickett and Cadenasso 2009). In addition to the human induced variability, in the Los Angeles Basin there is a steep natural gradient in temperature and humidity away from the coast, and significant topographic variation (Morris 2006). Heterogeneity in biotic and abiotic factors is likely to lead to significant variation in tree function, although this has seldom been tested in cities.

In order to study the factors which control whole tree water use of common species in the urban forest of the Los Angeles metropolitan region, we measured sap flow, meteorology, leaf and soil nutrients and isotopic composition, and hydraulic conductance in four urban forest sites experiencing a range of management intensities and climates. The focal species are commonly planted in the Los Angeles area: California sycamore (Platanus racemosa Nutt.) and Canary Island pine (Pinus canariensis C. Sm.). California sycamore is native to riparian and canyon habitats in the Southern California region (Hickman 1993; Holstein 1984); Canary Island pine is native to a Mediterranean climate that is similar to Southern California (Luis et al. 2005). We measured the same species at different sites and also compared the water relations of co-occurring species in order to address the following questions: How does water use vary between species? What is the degree of spatial heterogeneity in the water use of these species, and what are the apparent causes? Finally, how significant is the role of water stress in influencing water use in irrigated trees? We hope that these results will contribute to a better understanding of urban tree function and its temporal and spatial variability, particularly in irrigated, semi-arid environments.

\section{Methods}

\section{Site descriptions}

This study was conducted during 2007 at four locations within the Los Angeles Basin in California, USA, which includes portions of Los Angeles, Riverside, and San Bernardino Counties, and all of Orange County. The Basin is a coastal plain surrounded by peninsular and transverse mountain ranges. The climate is Mediterranean with an average annual temperature of $18.3^{\circ} \mathrm{C}$ and precipitation of $38 \mathrm{~cm}$ (downtown Los Angeles; Morris 2006). Precipitation occurs primarily in winter.

The study sites spanned a coastal-to-inland gradient (see Fig. 1), and ranged in intensity of human management from unmanaged to highly managed. All sites were composed of open grown trees (low tree density and wide spacing of trees, with little to no overlapping of individual tree canopies; Table 1). The "Natural" site was an unmanaged riparian forest located in Starr Ranch Sanctuary, a 4000 acre preserve in Trabuco Canyon, operated by the National Audubon Society (33.62 N, 117.56 W; 256 m elevation). The forest is composed of native California sycamore and Quercus agrifolia Nee. (coast live oak). This site receives no irrigation, fertilization or other management, although there is residential and commercial urban development in close proximity to the preserve. Unlike the other measurement sites, trees at this site were naturally established and were not planted. While much of the Los Angeles Basin contained shrubland and grassland ecosystems before urban development, there were natural riparian forests along waterways. This site served as a comparison between urban and a more "natural" or unmanaged forest in the region.

The "Unirrigated" site was located within an unirrigated and unfertilized section of the Los Angeles Zoo and Botanical Gardens (34.15 N, 118.29 W; 162 m elevation) in Los Angeles. Species in the measurement area included non-native Canary Island pine, a 


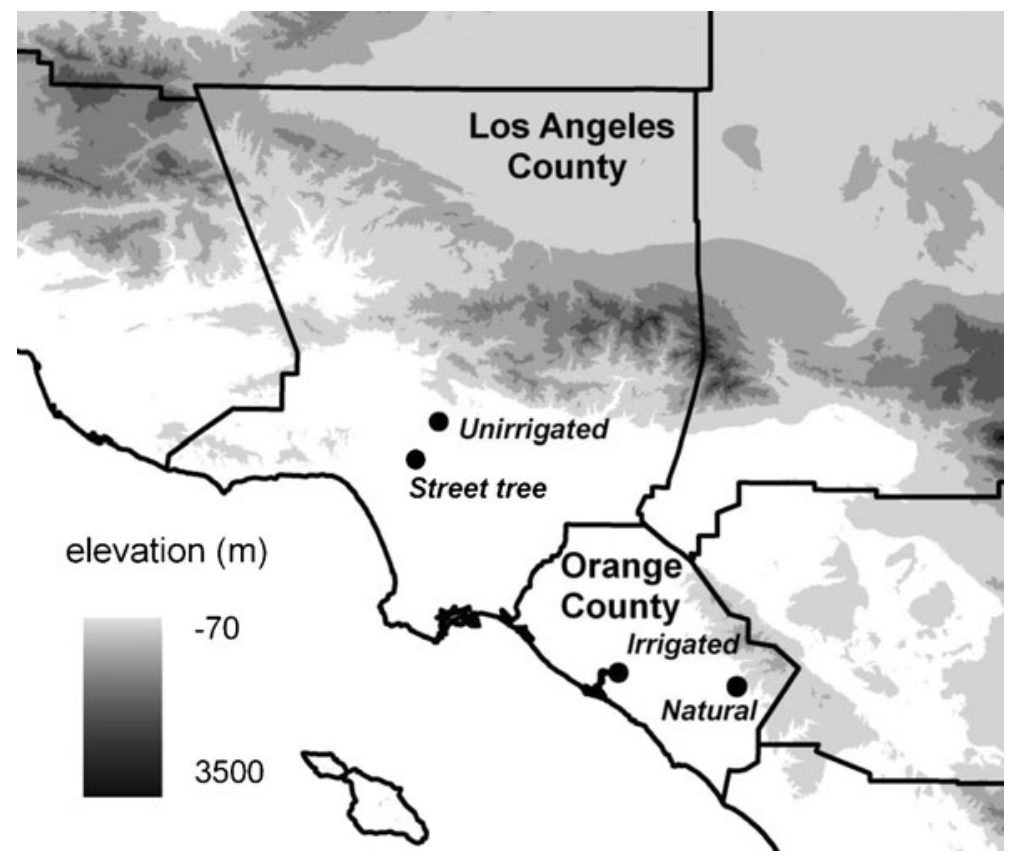

Fig. 1 Map of study region, indicating location of the four study sites relative to coast and mountains. Elevation data is from the National Elevation Dataset produced and distributed by the US Geological Survey, obtained through: http://seamless.usgs.gov

commonly planted street tree in Los Angeles. Although the trees were not directly irrigated during the period of this study, surrounding trees in the Zoo and Botanical Gardens were irrigated, and the unirrigated trees might be expected to receive some soil moisture from lateral transport in surrounding soils.

The "Irrigated" site was located on the campus of the University of California, Irvine (33.65 N, $117.85 \mathrm{~W} ; 19 \mathrm{~m}$ elevation). This area was not regularly fertilized, but was irrigated every 2-3 days during summer (less frequently at other times of year) with reclaimed water, which may have some fertilizing effects. Measured trees included individuals of the native California sycamore and the non-native Canary Island pine planted in a mixed lawn and groundcover garden setting. At this and all of our study sites, we did

Table 1 Characteristics of study trees and sites. Values in parentheses give the range in diameters and sapwood depths. Tree density was determined at the site level, and includes all trees of the same or larger size as study trees (including some trees which were not part of the study)

\begin{tabular}{lllllr}
\hline tree species & site & $\mathrm{n}$ & $\begin{array}{l}\text { average diameter } \\
(\mathrm{cm})\end{array}$ & $\begin{array}{l}\text { average sapwood } \\
\text { depth }(\mathrm{cm})\end{array}$ & $\begin{array}{l}\text { Tree density } \\
\text { (trees/ha) }\end{array}$ \\
\hline California sycamore & Irrigated & 5 & $47.5(36.3-67.2)$ & $8.0(5.3-10.5)$ & 103 \\
California sycamore & Street trees & 3 & $37.0(34.1-40.6)$ & $10.0(7.8-12.2)$ & 110 \\
California sycamore & Natural & 8 & $41.2(20.9-81.9)$ & $5.2(2.3-8.2)$ & 95 \\
Canary Island pine & Irrigated & 5 & $54.9(50.4-62.3)$ & $15.2(14.5-16.1)$ & 103 \\
Canary Island pine & Unirrigated & 7 & $43.7(28.8-51.0)$ & $14.9(13.3-16.2)$ & 134 \\
\hline
\end{tabular}


not control irrigation or fertilization, but relied on the practices of the individual land owner. In this way the study represents observations of actual urban land cover rather than a controlled experiment.

The most urbanized and human-altered study site was the "Street trees" site $(34.07 \mathrm{~N}$, 118.34 W; $70 \mathrm{~m}$ elevation), which consisted of native California sycamore growing in planting strips on a residential Los Angeles street. While the trees at this site were seldom directly irrigated or fertilized, they likely received runoff from nearby irrigated and fertilized lawns and gardens. Measurements were conducted from late June 2007 to late January 2008. Sample size and study tree characteristics are given in Table 1.

Atmospheric and soil moisture measurements

Temperature and relative humidity, from which vapor pressure deficit (VPD) was calculated, were measured continuously at approximately one-third to one-half of canopy height at all four sites (HMP45C, Vaisala Inc., Helsinki, Finland) for the duration of the study period. Photosynthetically active radiation (PAR; LI190SB, LiCor, Lincoln, NE, USA) was measured at the Natural and the Unirrigated sites. For the Street tree and Irrigated sites, PAR values were taken from the nearest California Irrigation Management Information System (CIMIS) station, accessed through: http://wwwcimis.water.ca.gov. All sites, except for the Street trees, had 2-6 soil moisture sensors ( $\theta$; CS616, Campbell Scientific, Logan, Utah, USA) inserted vertically into the top $0-30 \mathrm{~cm}$ of soil. Relative water content was derived from soil moisture as $\left(\theta-\theta_{\min }\right) /\left(\theta_{\max }-\theta_{\min }\right)$, where $\theta_{\min }$ and $\theta_{\max }$ were the minimum and maximum values of $\theta$ recorded at each site. All sensors were sampled every $30 \mathrm{~s}$, and 30-minute averages were logged (CR10X or CR1000, Campbell Scientific, Logan, Utah, USA).

\section{Sapflux measurements}

Measurements of sapflux density were conducted on mature individuals of California sycamore and Canary Island pine (sample sizes and tree diameter ranges shown in Table 1). At each of the four sites, 3-8 trees were equipped with $2 \mathrm{~cm}$ Granier-type thermal dissipation probes (after Granier 1987). Probes were placed in the outer $2 \mathrm{~cm}$ of xylem, on the north facing side of each tree. To deter vandalism, sensors at the Irrigated and Street tree sites were placed at 2.1-5.3 m above the ground. Output from sapflux sensors was sampled every $30 \mathrm{~s}$ and logged as $30 \mathrm{~min}$ averages. These outputs were converted to sapflux density in the outer sapwood $\left(J_{O} ; \mathrm{g} \mathrm{H}_{2} 0 \mathrm{~cm}^{-2} \mathrm{~s}^{-1}\right)$ according to the empirical formula of Granier (1987):

$$
J_{O}=119\left(\left(\frac{\Delta T_{\max }}{\Delta T}\right)-\Delta T\right)^{1.231}
$$

According to this formula, $J_{O}$ at the time of $\Delta \mathrm{T}_{\max }$ equals 0 . In order to account for potential nighttime sapflux, the maximum $\Delta \mathrm{T}$ measured for each night was taken as $\Delta \mathrm{T}_{\max }$ only when minimum nighttime VPD was $<0.2 \mathrm{kPa}$. When nighttime VPD was $>0.2 \mathrm{kPa}$, $\Delta \mathrm{T}_{\text {max }}$ from the earliest subsequent night meeting the VPD criteria was used. All fluxes were normalized to breast height $(1.35 \mathrm{~m})$ by multiplying the measured $J_{O}$ with the ratio of sapwood area at sensor height to sapwood area at breast height. Sapwood thickness was determined visually from cores taken between the two probes (and also at breast height if sensors were not located near breast height). 
Soil nutrient and isotope measurements

Soil cores were taken at the conclusion of the study, in February 2008, to characterize site quality. Soil (excluding the litter layer) was sampled in five locations per site using a $5 \mathrm{~cm}$ corer (AMS Inc., American Falls, Idaho). Cores were taken in $15 \mathrm{~cm}$ increments, to a total depth of $30 \mathrm{~cm}$, except at the Unirrigated site where the presence of bedrock at 20-30 cm precluded collection of $15-30 \mathrm{~cm}$ cores. Samples were stored at $0^{\circ} \mathrm{C}$ when not being actively processed. Samples were first sieved to remove all material $>2 \mathrm{~mm}$. Then a $40 \mathrm{~g}$ root-free subsample was separated out, and inorganic nitrogen was extracted by shaking soil with $100 \mathrm{~mL}$ of $\mathrm{KCl}$ for one hour (Perakis and Hedin 2001). The resulting solution was filtered on a vacuum line, and inorganic nitrogen (nitrate) concentrations were then determined on the filtrate by cadmium reduction (after Jones 1984). First, $17.5 \mathrm{~mL}$ of sample were combined with $3.0 \mathrm{~mL}$ of $\mathrm{NH}_{4} \mathrm{Cl}$ and $\sim 1 \mathrm{~g}$ of spongy cadmium. After being shaken for $90 \mathrm{~min}, 2.5 \mathrm{~mL}$ were pipetted into a cuvette along with $125 \mu \mathrm{L}$ of color reagent and absorbance was determined with a spectrometer (GENESYS 10 Vis, Thermo Fisher Scientific Inc, Waltham, MA, USA). Absorbance was converted to concentration $\left(\mu \mathrm{m} \mathrm{L}^{-1}\right)$ based on a standard curve.

Solid (soil) material remaining from inorganic nitrogen extraction was dried for $>3$ days at $60^{\circ} \mathrm{C}$. After soil was separated from the glass filter, it was homogenized and 15-60 mg (depending on site and soil depth) was weighed into tin capsules. Samples were analyzed for organic nitrogen $(\% \mathrm{~N})$ and carbon $(\% \mathrm{C})$ concentrations and organic nitrogen isotope signature $\left(\delta^{15} \mathrm{~N}\right)$ with an elemental analyzer (Carlo Erba NA $1500 \mathrm{NC}$, Milan, Italy) coupled to an isotope ratio mass spectrometer (Thermofinnigan Delta Plus, San Jose, CA, USA). Isotope ratios are expressed in conventional $\delta$ notation and referenced to the atmospheric standard for $\delta^{15} \mathrm{~N}$. Concentrations are presented on a mass basis, and the precision of the measurements was $<0.01,0.02,0.08$ and 0.09 for $\% \mathrm{~N}, \% \mathrm{C}, \mathrm{C} / \mathrm{N}$ and $\delta^{15} \mathrm{~N}$ respectively.

\section{Leaf nutrient and isotope measurements}

Leaf chemistry $(\% \mathrm{~N}, \% \mathrm{C}, \mathrm{C} / \mathrm{N})$ and isotopes $\left(\delta^{15} \mathrm{~N}, \delta^{13} \mathrm{C}\right)$ were measured on $5-15$ lower canopy (but sunlit) leaves per tree, collected prior to California sycamore leaf fall (September). Leaves were dried at $60^{\circ} \mathrm{C}$ for $>3$ days, then dipped in liquid nitrogen and ground to a fine powder with a mortar and pestle. Approximately $1.5 \mathrm{mg}$ of homogenized leaves were weighed into tin capsules and analyzed with an elemental analyzer (Carlo Erba NA $1500 \mathrm{NC}$, Milan, Italy) coupled to an isotope ratio mass spectrometer (Thermofinnigan Delta Plus, San Jose, CA, USA). Isotope ratios are expressed in conventional $\delta$ notation and referenced to the PDB standard for $\delta^{13} \mathrm{C}$ and the atmospheric standard for $\delta^{15} \mathrm{~N}$. Concentrations are presented on a mass basis. The precision of these samples was 0.07 , $1.59,0.38,0.16$ and 0.25 for $\% \mathrm{~N}, \% \mathrm{C}, \mathrm{C} / \mathrm{N}, \delta^{15} \mathrm{~N}$ and $\delta^{13} \mathrm{C}$ respectively.

Plant hydraulics measurements

Hydraulic conductivity and vulnerability to cavitation were measured on one lower canopy branch collected from each study tree during fall or winter 2007/2008, according to the procedures of Sperry et al. (1988) and Alder et al. (1997). In the field, collected branches $(\sim 3-10 \mathrm{~mm}$ diameter) were cut to $\sim 20 \mathrm{~cm}$ length and stored in a sealed bag with wet paper towels. In the lab, samples were kept refrigerated until measurement ( $<1$ week). Samples were trimmed underwater to $14 \mathrm{~cm}$ length and bark was stripped from the ends. Stems were 
flushed for $1 \mathrm{~h}$ at $100 \mathrm{kPa}$, and then transferred to the conductivity measurement system, consisting of a balance connected by tubing to an IV bag of ultrapure water (Epure, Barnstead, Dubuque, IA, USA). Samples were then cycled between the conductivity system and a centrifuge (Sorvall RC 5C Plus, Thermo Fisher Scientific Inc, Waltham, MA, USA) where they were spun for $5 \mathrm{~min}$ at a time at increasing speeds (inducing decreasing stem water potentials) until conductivity ceased. Conductivity $(K)$ at $0.25 \mathrm{MPa}$ was used as maximum $K$ for the purpose of determining the pressure at which $50 \%$ loss of $K$ occurred $\left(\mathrm{P}_{50}\right)$.

\section{Whole tree transpiration}

Due to constraints on sensor placement, sapflux was measured only in the outer $2 \mathrm{~cm}$ of each study tree. However, it is well known that sapflux is not constant across the entire sapwood depth (e.g. Ford et al. 2004a; Nadezhdina et al. 2002; Phillips et al. 1996). Given that the sapwood depths of the study trees ranged up to $12 \mathrm{~cm}$ for California sycamore and up to $16 \mathrm{~cm}$ for Canary Island pine, accurate calculation of whole tree transpiration necessitated an estimation of the radial pattern of sapflux density. Most studies on radial trends in sapflux density have suggested that radial trends cannot be generalized, and must be measured for each species and set of environmental conditions (e.g. Ford et al. 2004b; Gebauer et al. 2008; Saveyn et al. 2008). However, a recent literature survey of radial trends data, incorporating 34 species (17 diffuse porous species, 8 ring porous species, and 9 gymnosperms) found a fairly consistent pattern of inner sapflux relative to sapflux in the outer $2 \mathrm{~cm}$ of sapwood (Pataki et al. in review). Based on the strength and consistency of these relationships $\left(R^{2}=0.63\right.$ for angiosperms and $R^{2}=0.76$ for gymnosperms $)$, and the lack of any species specific information on radial trends for the study species, we employed the generalized Gaussian relationships developed by Pataki et al. (in review):

$$
\begin{aligned}
& \text { angiosperm } J_{i} / J_{O}=1.033 * \exp \left(-0.5\left(\frac{x-0.09963}{0.4263}\right)^{2}\right) \\
& \text { gymnosperm } J_{i} / J_{O}=1.257 * \exp \left(-0.5\left(\frac{x+0.3724}{0.6620}\right)^{2}\right)
\end{aligned}
$$

Where $J_{i}$ is the sapflux density in a given layer and $\mathrm{x}$ is relative depth within the sapwood. These functions were applied at $2 \mathrm{~cm}$ intervals, to the average $J_{O}$ and sapwood depth for each species (and site), then multiplied by the sapwood area of each layer $\left(A_{i}\right)$, to obtain the transpiration from each layer of sapwood. Whole tree transpiration $(E)$ was calculated by summing the transpiration of each layer:

$$
E=\sum_{i=1}^{n} J_{i} A_{i}
$$

Standard deviation of whole tree transpiration at each site was calculated according to error propagation rules for multiplication (error within each sapwood layer) and addition (total error across all layers), as in Pataki et al. (in review). The error within each sapwood layer reflects the variability in the $J_{O}$ measurement (i.e. tree to tree variability), as well as the error of the radial trends regression estimates (Eqs. 2, 3; $\sigma=0.2583$ for angiosperms and 0.1714 for gymnosperms). 
Statistical methods

Relationships between $J_{O}$ and VPD for each 4-6 week time period were fitted for each tree with natural logarithm functions $(y=a * \ln (V P D)+b)$ and tested for overall significance $(\alpha=$ 0.05 ) with SigmaPlot (Version 10, Systat Software Inc). Parameters of these fits were used as replicates to test for time and site effects using repeated measures ANOVA within Proc Mixed in SAS (Version 9.2, The SAS Institute, Cary, NC). Subsequently the same procedure was used to fit a single relationship (for each tree) across the entire measurement period, excluding days with $\mathrm{RWC}<0.5$. Residuals from this relationship were regressed linearly, and tested against daylength corrected PAR (total daily PAR / hours of daylight) using SigmaPlot, and then residuals from the PAR relationship were regressed either logarithmically or linearly (depending on best fit) and tested against RWC. Within-species differences in leaf $\mathrm{C} / \mathrm{N}$ ratio and isotopes $\left(\delta^{15} \mathrm{~N}, \delta^{13} \mathrm{C}\right)$, and the parameters of sigmoidal $(\mathrm{y}=\mathrm{a} /(1+\exp (-(\mathrm{x}-\mathrm{x} 0) / \mathrm{b})))$ fits of hydraulic conductivity $(K)$ and percent loss of conductivity (\% loss of $K$ ) to stem water potential, were tested with Proc Mixed in SAS, with Tukey corrections for multiple comparisons. Across site differences in soil $\% \mathrm{~N}, \% \mathrm{C}$, inorganic $\mathrm{N}$ concentration, $\mathrm{C} / \mathrm{N}$ and $\mathrm{N}$ isotopes were tested in the same way.

\section{Results}

Climate

Climatic conditions over the course of the experiment are shown in Fig. 2. Average daytime temperatures peaked at the beginning of September at $30-35^{\circ} \mathrm{C}$ (depending on site) and declined gradually thereafter. The average daytime VPD reached highs of $3-$ $4 \mathrm{kPa}$. Episodes of high VPD occurred throughout the measurement period, usually associated with Santa Ana wind conditions, which is a reversal in the direction of the sea breeze due to high pressure systems in the inland deserts. The gradient of increasing temperature and VPD with distance from the coast was not as pronounced as expected, with the Irrigated site (closest to the coast; Fig. 1) experiencing lower average temperatures and VPDs only in the early and mid parts of the summer (Fig. 2a,b). Daily PAR declined from highs of $\sim 60 \mathrm{~mol} \mathrm{~m}^{-2} \mathrm{~d}^{-1}$ in June to $\sim 25 \mathrm{~mol} \mathrm{~m}^{-2} \mathrm{~d}^{-1}$ in December (Fig. 2c). Daily PAR was fairly similar across the sites, except at the Unirrigated site, where it was lower, likely due to topographic effects (the site is located on a steep hillslope).

The most notable difference in environmental factors across the sites was the dramatic difference in soil water content due to the presence (Irrigated site) or absence (Unirrigated, Natural sites) of irrigation (Fig. 2d). Unfortunately, the location of the Street Tree site (a public street) precluded the placement of soil moisture sensors. For the Natural site, relative soil water content (RWC) in the shallow soil layer remained extremely low $(\sim 3 \%)$ for the duration of the experiment, as no precipitation occurred for the duration of monitoring at that site (data is only reported for the period prior to leaf senescence of California sycamore). The Unirrigated site experienced similarly low RWC until the start of October, when the winter rains began. RWC at the Irrigated site was maintained at a high level throughout the summer due to irrigation, but subsequently experienced greater variability (including some very low contents) when irrigation was reduced. Overall, microclimates were similar across the sites, with the obvious exception of differing irrigation regimes. 


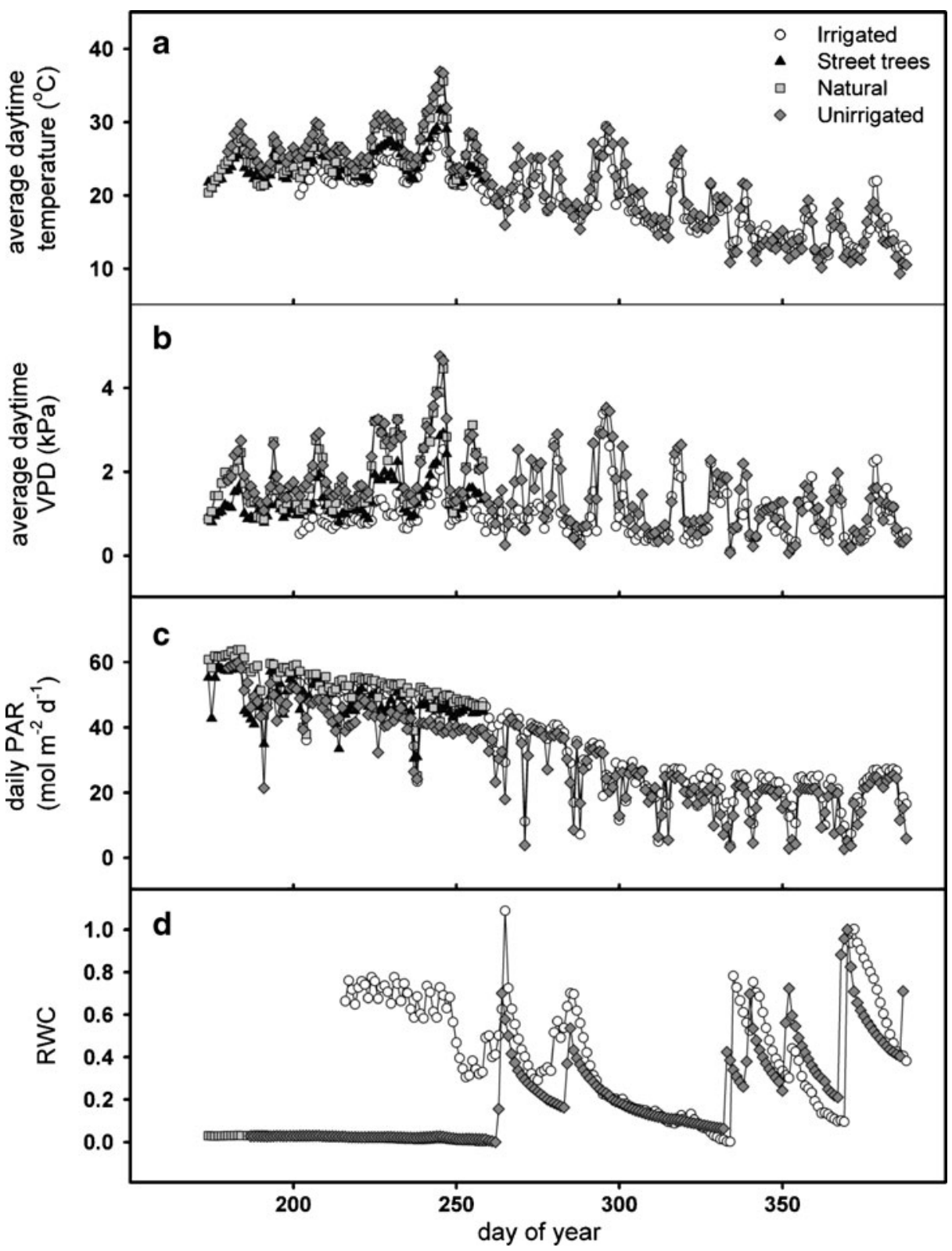

Fig. 2 Average daytime temperature (a), average daytime vapor pressure deficit (VPD;b), daily photosynthetically active radiation $(\mathrm{PAR} ; \mathbf{c})$ and relative water content $(\mathrm{RWC} ; \mathbf{d})$ at the Irrigated, Street tree, Natural and Unirrigated sites

Sapflux responses to environmental drivers

Sapflux data for California sycamore was divided into three equal time periods in order to detect seasonal changes in responses to VPD (Fig. 3). Data after September 15 was 
Fig. 3 Average daily sapflux in the outer $2 \mathrm{~cm}\left(J_{O}\right)$ of California sycamore as a function of vapor pressure deficit (VPD) during early summer (a), mid summer (b) and late summer (c). Error bars represent 1 SE. Logarithmic fits $(\mathrm{y}=\mathrm{a} * \ln (V P D)+\mathrm{b})$ are shown for the average $J_{O}$ of each site

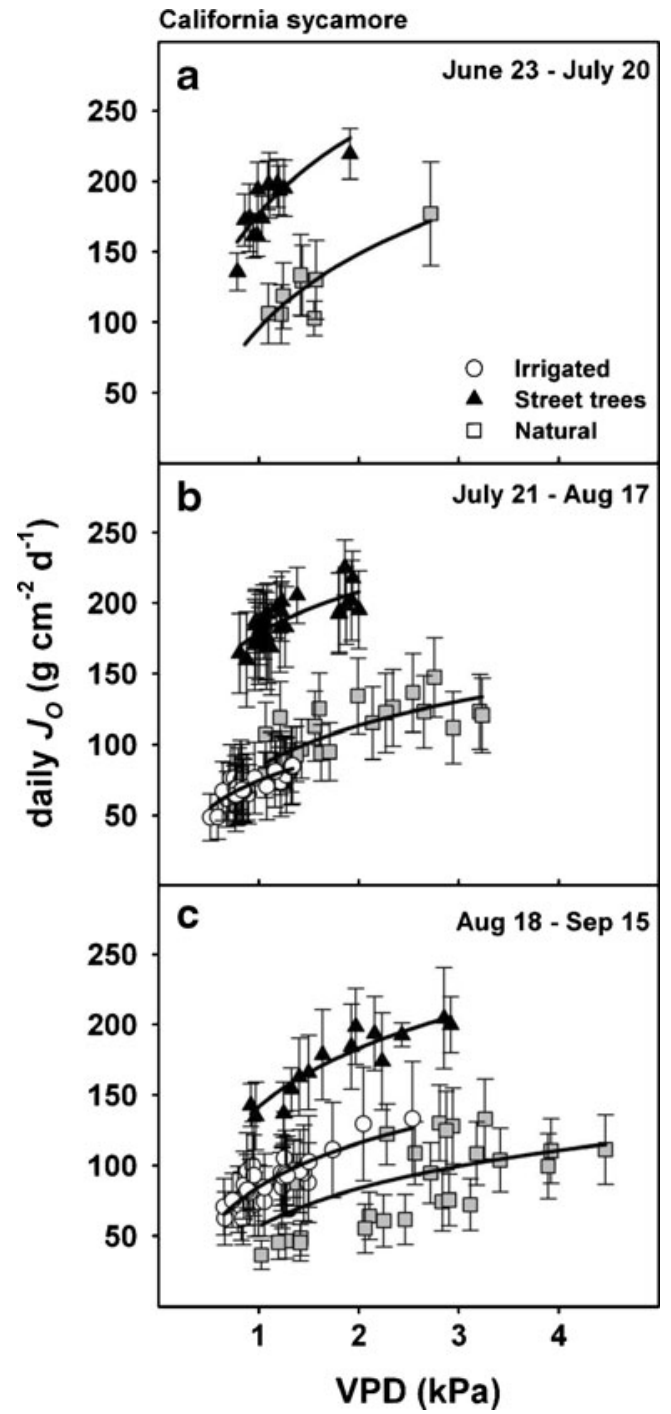

excluded from analysis, as this marked the beginning of leaf senescence. During the early summer, California sycamore Street trees had higher $\left(\sim 75 \mathrm{~g} \mathrm{~cm}^{-2} \mathrm{~s}^{-1}\right)$ daily $J_{O}$ for the same VPD compared to Natural sycamores, and VPD was generally low (Fig. 3a; Table 2); measurements of Irrigated sycamores had not yet begun. The difference between Street trees and Natural trees was maintained for the rest of the summer, when Street trees had higher $J_{O}$ at the same VPD than either the Natural or Irrigated trees (Fig. 3b,c; Table 2). While Irrigated trees experienced a smaller range of VPD than Natural trees, both had a similar response to VPD. Repeated measures ANOVA of the $J_{O}$-VPD regression parameters showed a significant decline in both parameters over the season, driven primarily by the Street trees and Natural sites. Separation of daily $J_{O}$ into morning and afternoon VPD relationships showed no hysteresis (data not 
Table 2 Average parameters and $\mathrm{R}^{2}$ of daily sapflux $\left(J_{O}\right)$ vs. daily average vapor pressure deficit (VPD) relationships of the form $y=a * \ln (V P D)+b$. Standard errors are shown in parentheses and superscripts indicate cross site differences within each time period, according to least squared difference $(\alpha=0.05)$ within a repeated measures ANOVA

\begin{tabular}{llllllllll}
\hline California sycamore & \multicolumn{2}{l}{ Irrigated } & \multicolumn{9}{c}{ Street trees } & \multicolumn{3}{c}{ Natural } & \\
& a & $\mathrm{b}$ & $\mathrm{R}^{2}$ & $\mathrm{a}$ & $\mathrm{b}$ & $\mathrm{R}^{2}$ & $\mathrm{a}$ & $\mathrm{b}$ & $\mathrm{R}^{2}$ \\
June 23-July 20 & & & & 83.7 & 173.9 & 0.74 & 67.0 & 103.7 & 0.76 \\
& & & & $(4.7)^{\mathrm{a}}$ & $(15.4)^{\mathrm{a}}$ & $(0.05)$ & $(19.7)^{\mathrm{a}}$ & $(20.5)^{\mathrm{b}}$ & $(0.07)$ \\
July 21-Aug 17 & 29.3 & 74.7 & 0.33 & 56.6 & 167.6 & 0.58 & 33.2 & 88.5 & 0.46 \\
& $(11.1)^{\mathrm{a}}$ & $(24.1)^{\mathrm{a}}$ & $(0.11)$ & $(6.3)^{\mathrm{a}}$ & $(19.3)^{\mathrm{b}}$ & $(0.12)$ & $(11.4)^{\mathrm{a}}$ & $(17.0)^{\mathrm{a}}$ & $(0.10)$ \\
Aug 18-Sept 15 & 43.5 & 78.5 & 0.56 & 54.3 & 144.5 & 0.59 & 31.2 & 56.7 & 0.41 \\
& $(16.6)^{\mathrm{a}}$ & $(24.3)^{\mathrm{ab}}$ & $(0.11)$ & $(13.8)^{\mathrm{a}}$ & $(19.3)^{\mathrm{a}}$ & $(0.15)$ & $(9.2)^{\mathrm{a}}$ & $(13.4)^{\mathrm{b}}$ & $(0.08)$ \\
Canary Island pine & Irrigated & & & Unirrigated & & & & \\
& $\mathrm{a}$ & $\mathrm{b}$ & $\mathrm{R}^{2}$ & $\mathrm{a}$ & $\mathrm{b}$ & $\mathrm{R}^{2}$ & & & \\
July 20-Sept 4 & 14.4 & 69.4 & 0.17 & & & & & & \\
& $(9.9)$ & $(6.5)$ & $(0.11)$ & & & & & & \\
Sept 5-Oct 20 & 20.7 & 57.6 & 0.22 & 0 & 15.9 & 0 & & & \\
& $(9.0)^{\mathrm{a}}$ & $(10.8)^{\mathrm{a}}$ & $(0.07)$ & $(0)^{\mathrm{a}}$ & $(6.8)^{\mathrm{b}}$ & $(0)$ & & & \\
Oct 21-Dec 5 & 5.7 & 30.3 & 0.23 & 4.8 & 11.0 & 0.24 & & & \\
& $(2.2)^{\mathrm{a}}$ & $(4.0)^{\mathrm{a}}$ & $(0.07)$ & $(3.9)^{\mathrm{a}}$ & $(4.6)^{\mathrm{b}}$ & $(0.12)$ & & & \\
Dec 6-Jan 23 & 17.1 & 45.0 & 0.58 & 15.8 & 37.5 & 0.36 & & & \\
& $(1.9)^{\mathrm{a}}$ & $(6.0)^{\mathrm{a}}$ & $(0.10)$ & $(3.7)^{\mathrm{a}}$ & $(8.3)^{\mathrm{b}}$ & $(0.05)$ & & & \\
\hline
\end{tabular}

shown), indicating that site differences did not result from earlier stomatal closure in some sites.

Because of the longer data record for the evergreen Canary Island pine, sapflux data was split into four equal time periods to look for seasonal variation in the response to VPD (Fig. 4). During the first two periods (until mid October), $J_{O}$ was much greater in the Irrigated site than in the Unirrigated site (Fig. 4a,b; Table 2). Notably, at the beginning of the study period, $J_{O}$ at the Unirrigated site was below detectable limitsthat is, there was no detectable diurnal signal from the sap flow sensors indicating that the flux was very low. However, by mid October, $J_{O}$ had declined at the Irrigated site, and was more similar (although still greater) to the Unirrigated site (Fig. 4c). Finally, after several months of rain, $J_{O}$ was similar in both sites during the winter period (Fig. 4d; Table 2). In contrast to California sycamore, the correlation of $J_{O}$ with VPD was generally weak for Canary Island pine, with $\mathrm{R}^{2}$ values below 0.25 early in the study (Table 2).

In order to explain the remaining variability in $J_{O}$, the residuals of the $J_{O}$-VPD relationships (refit for the entire measurement period) were regressed against daylength corrected PAR, then against RWC. Where possible, VPD and PAR regressions were restricted to RWC $>0.5$. This criteria was not applied to the Street trees site (for which soil moisture measurements were not available) or the Natural site (where RWC was always below 0.5 ). For California sycamore, PAR was only a significant driver of $J_{O}$ in the Street trees and Natural sites, with a weaker relationship at the Natural site (Fig. 5a, Table 3). PAR was not a significant factor at the Irrigated site. For Canary Island pine, PAR was a significant driver of $J_{O}$ only at the Irrigated site (Fig. 5c). Finally, soil water content was a driver of $J_{O}$ for California sycamore at the Natural site (but not the Irrigated 


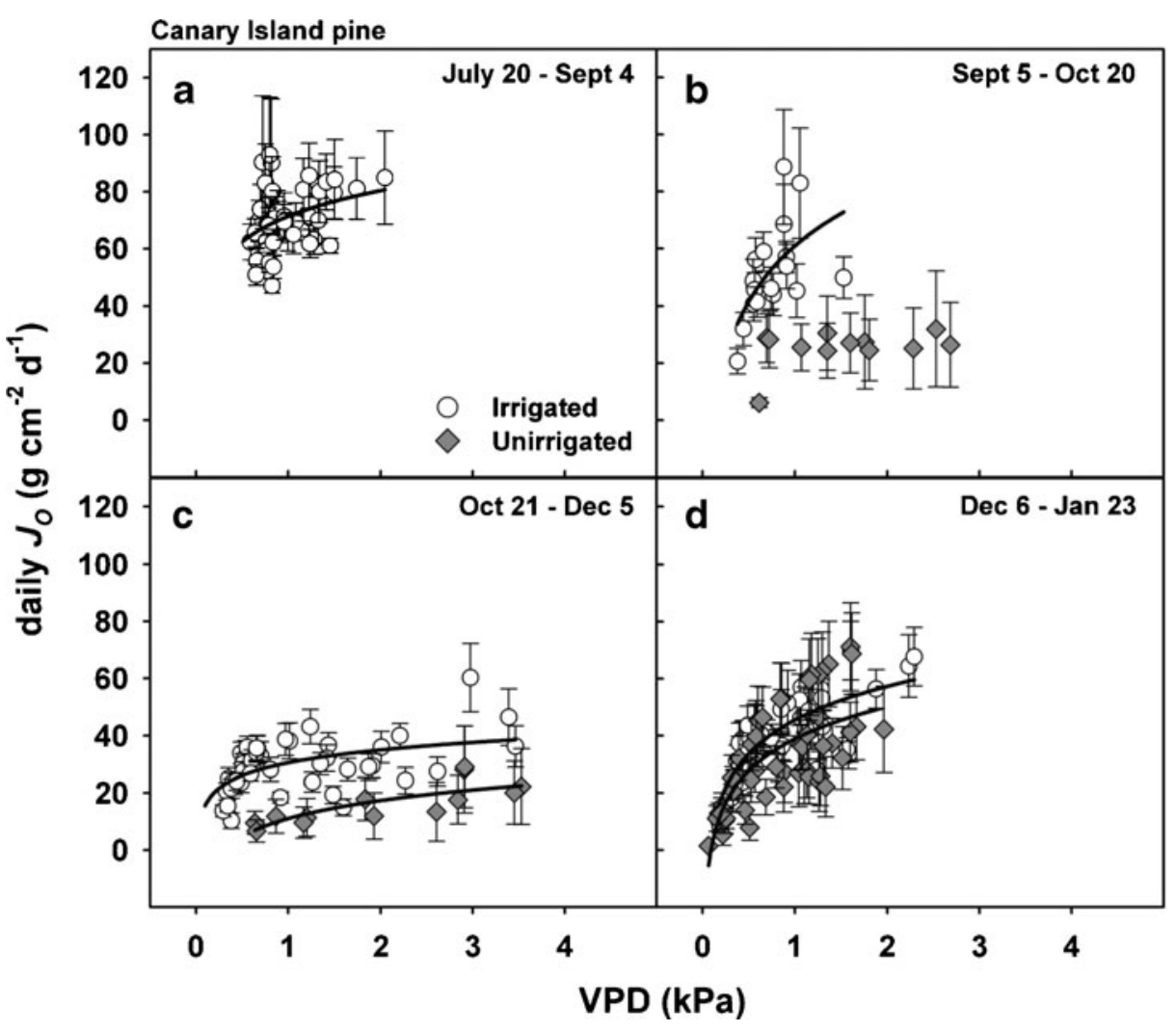

Fig. 4 Average daily sapflux in the outer $2 \mathrm{~cm}\left(J_{O}\right)$ of Canary Island pine as a function of vapor pressure deficit (VPD) during summer (a), early fall (b), late fall (c) and early winter (d). Logarithmic fits ( $\mathrm{y}=\mathrm{a} * \ln$ $(\mathrm{VPD})+\mathrm{b})$ of the average $J_{O}$ of each site are shown only for relationships significant at $\alpha=0.05$. Error bars represent $1 \mathrm{SE} . J_{O}$ at the Unirrigated site at time (A) was below detectable limits and is therefore not shown

site) and for Canary Island pine at both the Irrigated and Unirrigated sites (Fig. 5b,d; Table 3).

Soil organic nutrients and isotopes

Analysis of organic soil nitrogen and total carbon indicated no significant differences $(p>$ 0.05 ) across the sites in $\% \mathrm{C}$ at $0-15 \mathrm{~cm}$ or $15-30 \mathrm{~cm}$ depth, and no significant difference in $\% \mathrm{~N}$ at $15-30 \mathrm{~cm}$ depth (Table 4). However there was a trend toward higher $\% \mathrm{C}$ at the Irrigated and Street trees sites and significantly lower $\% \mathrm{~N}$ at the Natural site at the $0-15 \mathrm{~cm}$ depth. Soil $\% \mathrm{~N}$ was highest in the Street trees site. $\mathrm{C} / \mathrm{N}$ ratio was significantly higher at the Irrigated site than the other sites (at $0-15 \mathrm{~cm}$ ), and significantly lower at the Natural site $(15-30 \mathrm{~cm})$. Isotope ratios of soil nitrogen $\left(\delta^{15} \mathrm{~N}\right)$ were significantly enriched at the Irrigated and Street trees sites compared to the Natural and Unirrigated sites at both soil depths. Although not statistically different due to high variability, inorganic $\mathrm{N}$ concentration ( $\mu \mathrm{g} \mathrm{N} \mathrm{g}^{-1}$ moist soil) was nearly ten times higher at the Street tree site than the other sites (Table 4). Overall, these measurements indicate more favorable soil nutrient conditions in the Irrigated and Street tree sites, and distinct N sources or N cycling (e.g. losses) resulting in isotopic enrichment. 


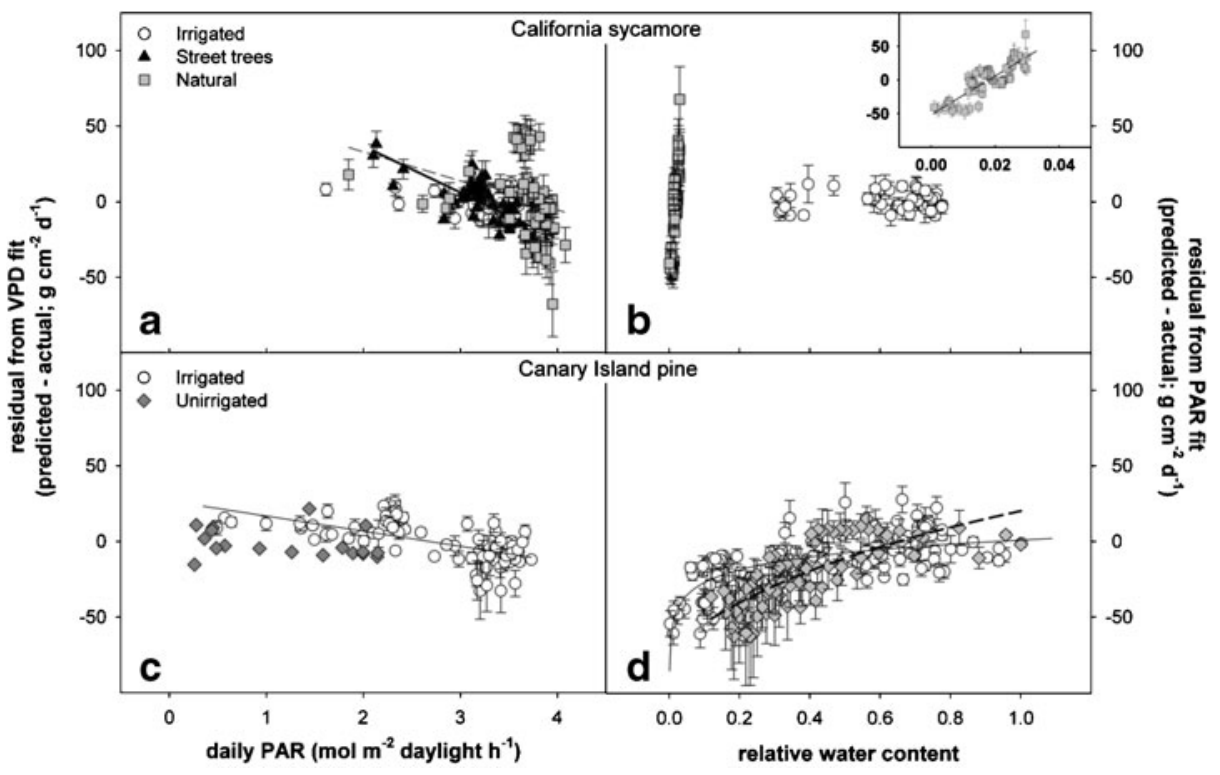

Fig. 5 Residuals (predicted - actual) from the relationship of $J_{O}$ versus vapor pressure deficit (VPD) as a function of daylength adjusted photosynthetically active radiation (PAR) during periods of relative water content $(\mathrm{RWC})>0.5$ (for Irrigated and Unirrigated sites) for California sycamore (a) and Canary Island pine (c). Residuals (predicted - actual) from the relationship of VPD residuals versus photosynthetically active radiation (PAR), as a function of relative water content (RWC) across the entire study period for California sycamore (b) and Canary Island pine (d). Inset in (b) has the same axes as (b), but truncated to show the response of the Natural site to RWC. Linear fits in $(a, b, c)$ and logarithmic $(y=a * \ln (R W C)+b)$ fits in $(d)$ to the average residuals of each site are shown only for relationships significant at $\alpha=0.05$. Error bars in all panels represent $1 \mathrm{SE}$. For the fits in a,b the thin line represents the Irrigated site, the thick line represents the Street trees site and the dashed line represents the Natural site. For fits in c,d the thin lines represents the Irrigated site and the thick dashed line represents the Unirrigated site

\section{Leaf isotopes and nutrients}

California sycamores at the Natural site had a significantly more enriched $\delta^{13} \mathrm{C}$ than either Street tree site species (Table 4). Trees at the Natural site also had distinctly more depleted leaf $\delta^{15} \mathrm{~N}$ than the two urban, managed sites. Finally, the $\mathrm{C} / \mathrm{N}$ ratio of leaves at the Natural

Table 3 Average contribution of daily vapor pressure deficit (VPD), photosynthetically active radiation (PAR) and relative water content (RWC) to explanation of variability in daily sapflux $\left(J_{O}\right)$. The determination of the contribution of each factor proceeded as described in the text: beginning with VPD and each subsequent factor being used to explain residuals. Standard errors are shown in parentheses

\begin{tabular}{lllll}
\hline & VPD R & PAR R & RWC R & Total R $^{2}$ \\
\hline California sycamore & & & \\
Irrigated & $0.45(0.16)$ & $0(0)$ & $0.03(0.03)$ & $0.49(0.15)$ \\
Street trees & $0.35(0.15)$ & $0.28(0.08)$ & & $0.63(0.07)$ \\
Natural & $0.16(0.05)$ & $0.02(0.01)$ & $0.43(0.08)$ & $0.61(0.06)$ \\
Canary Island pine & & & $0.15(0.03)$ & $0.74(0.02)$ \\
Irrigated & $0.40(0.04)$ & $0.18(0.05)$ & $0.14(0.05)$ & $0.86(0.04)$ \\
Unirrigated & $0.71(0.07)$ & $0(0)$ & & \\
\hline
\end{tabular}




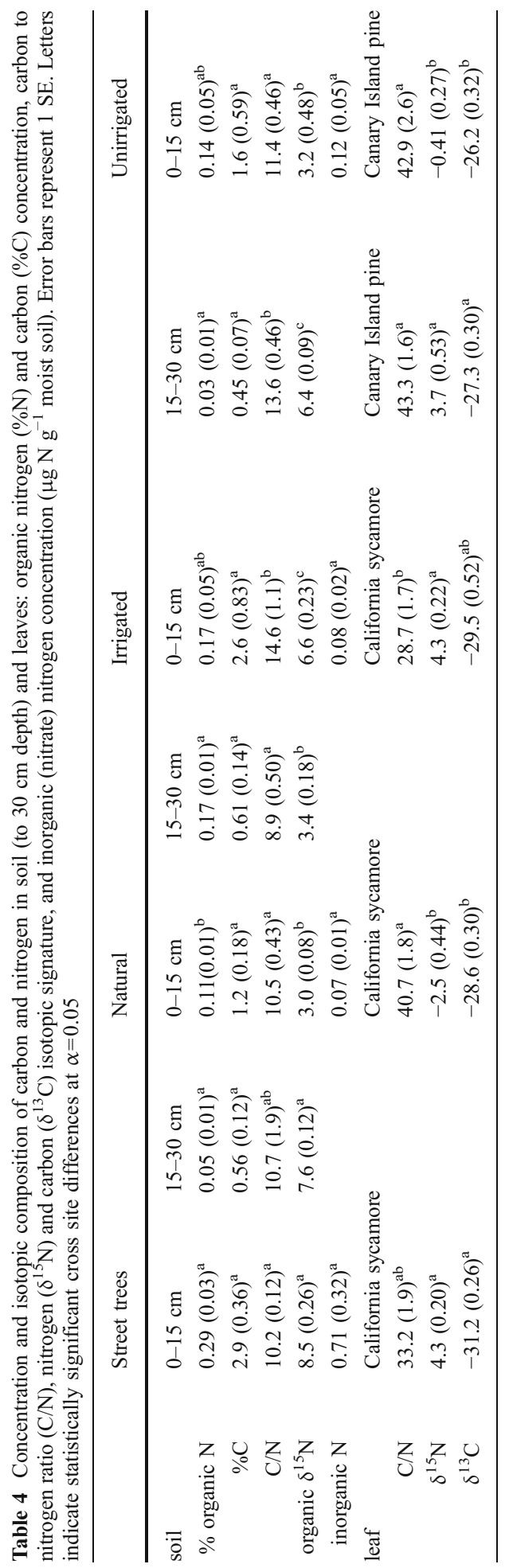


site was higher than the urban sites. Within Canary Island pines, the Irrigated and Unirrigated sites had significantly different $\delta^{13} \mathrm{C}$ and $\delta^{15} \mathrm{~N}$. However, the $\mathrm{C} / \mathrm{N}$ ratio was not different across the two sites (Table 4).

\section{Hydraulics}

We evaluated hydraulic conductivity $(K)$ and vulnerability to cavitation (\% loss of $K$ ) to compare species, and also to determine if plant hydraulics varied within species, in response to growth under different environmental conditions. Growth environment (i.e. different water and nutrient availabilities) had a limited impact on stem hydraulics for California sycamore and Canary Island pine. There were no significant differences in $\mathrm{P}_{50}, \mathrm{P}_{75}$, or functional (i.e. at $0.25 \mathrm{MPa}$ ) maximum stem area-specific $K$ between California sycamore at the Natural, Irrigated or Street sites (all $p>0.05$; Fig. 6). For Canary Island pine, maximum stem area-specific $K$ was higher at the Unirrigated compared to the Irrigated site (1142 vs. $\left.606 \mathrm{mg} \mathrm{mm}^{-1} \mathrm{Mpa}^{-1} ; p=0.043\right)$, but there were no differences in $\mathrm{P}_{50}$ or $\mathrm{P}_{75}(p=$ 0.814 and $p=0.714$ ). However, \% loss of $K$ and maximum $K$ were very different between California sycamore and Canary Island pine. Site-averaged $\mathrm{P}_{50}$ ranged from -1.5 to $-2.0 \mathrm{MPa}$ for California sycamore and -5.2 to $-5.4 \mathrm{MPa}$ for Canary Island pine (Fig. 6a,b), while maximum stem area-specific $K$ ranged from $2559-3525 \mathrm{mg} \mathrm{mm}^{-1} \mathrm{~s}^{-1} \mathrm{MPa}^{-1}$ for California sycamore and $606-1142 \mathrm{mg} \mathrm{mm}^{-1} \mathrm{~s}^{-1} \mathrm{MPa}^{-1}$ for Canary Island pine (Fig. 6c,d). Thus, Canary Island pine had a much lower $K$ and was much more resistant to cavitation than California sycamore.

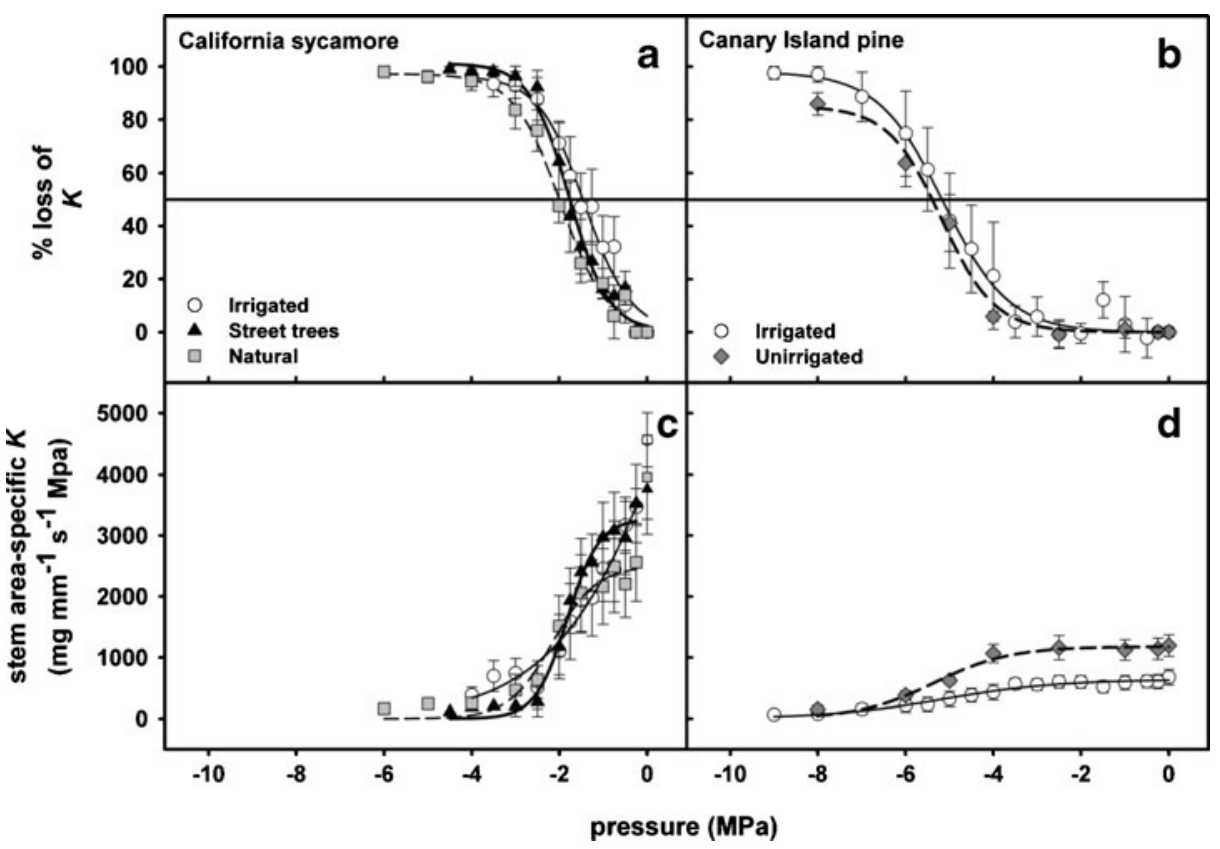

Fig. 6 Percent loss of conductivity ( $\%$ loss of $K$ ) and stem area-specific $K$ for California sycamore (a,c) and Canary Island pine $(\mathbf{b}, \mathbf{d})$. Sigmoidal $(\mathrm{y}=\mathrm{a} /(1+\exp (-(\mathrm{x}-\mathrm{x} 0) / \mathrm{b})))$ fits for stem area-specific $K$ were made excluding the $K$ value at $\mathrm{MPa}=0$. For the fits in a,c the thin line represents the Irrigated site, the thick line represents the Street trees site and the dashed line represents the Natural site. For fits in b,d the thin lines represents the Irrigated site and the thick dashed line represents the Unirrigated site. Error bars indicate $1 \mathrm{SE}$ 
Whole tree transpiration

Equations 2 and 3 were used to scale $J_{O}$ to the whole tree level to compare absolute values of whole tree water use among species and sites. Daily $E$ of California sycamore at the Street tree and Natural sites was fairly constant over the study period (with the exception of the last $\sim 10$ days at the Natural site). In contrast, daily $E$ at the Irrigated site gradually increased over the study period (Fig. 7a). Overall, daily $E$ at the Street tree site was approximately double the values at the Irrigated and Natural sites, peaking around $130 \mathrm{~kg} \mathrm{~d}^{-1}$. For Canary Island pine, the Irrigated site generally showed a decline in $E$ as daily PAR values declined (Fig. 7b). At the Unirrigated site, where summer and fall $E$ was very low due to low water availability, $E$ actually increased during the winter period. As with $J_{O}, E$ at the Irrigated site was higher than at the Unirrigated site until the winter period, when both sites had similar $E$. In contrast to $J_{O}$, which was much higher for California sycamore than Canary Island pine, tree level $E$ (assessed during the same time period) was similar for both species, due to the greater sapwood area of Canary Island pines.

\section{Discussion}

We found that the native California sycamore had higher rates of $J_{O}$ than the non-native Canary Island pine. Both species showed considerable site-to-site variability in the magnitude of water flux and its seasonality. Water availability was the primary driver for inter-site differences in Canary Island pine, as the response to VPD at both sites was similar during a period without water limitations. Causes of variability in $J_{O}$ of California sycamore were more complex: some of the variability may have been driven by water availability, but also by nutrient availability, reflected in leaf and soil $\mathrm{N}$ and isotope measurements. California sycamore did not appear to experience water stress even at the unirrigated Natural site, in contrast to Canary Island pine. Hydraulic capacity of these species was not influenced by differing water or nutrient availabilities. Whole tree transpiration $(E)$ was similar for the two species when water was not limiting, but Canary Island pine was able to survive with less water than California sycamore. Some of our results likely reflect genetic

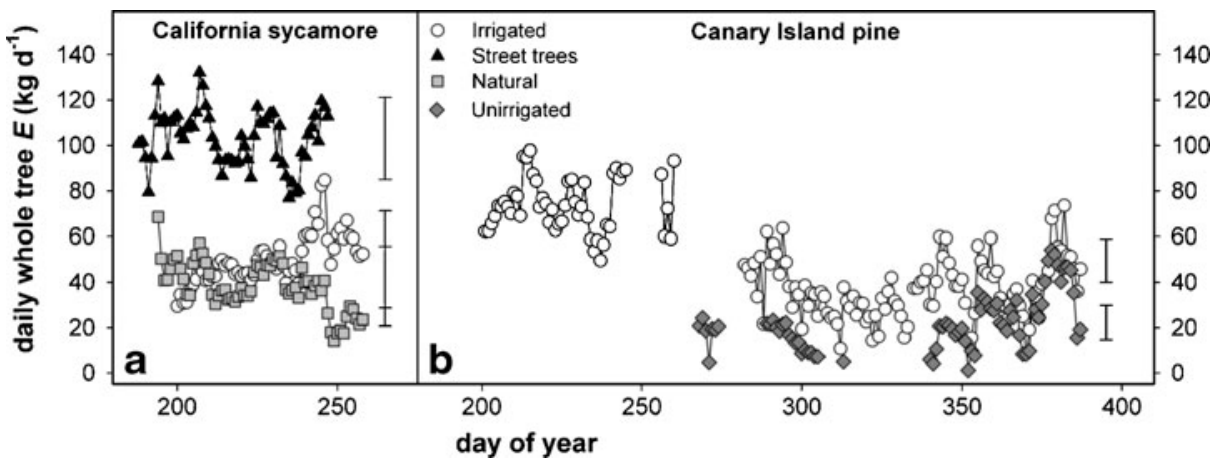

Fig. 7 Daily whole tree transpiration $(E)$ for California sycamore (a) and Canary Island pine (b) over the study period. Error bars shown at the end of each series represent the average SD over the entire study period, calculated through error propagation (as described in text). $E$ at the Unirrigated site prior to day 270 was below detectable limits and is therefore not shown 
differences in these species, which are adapted to very different habitats, while others show the influence of environmental conditions.

\section{Cross-species comparisons of water use}

We found that the native species (California sycamore) had higher rates of $J_{O}$ than the nonnative (Canary Island pine) species. This likely reflects the habitats to which each of these species is adapted in their native environments. California sycamore, while native to the Southern California region, is a phreatophyte that naturally occurs in riparian and canyon habitats (Hickman 1993; Holstein 1984) and is therefore adapted to conditions of shallow groundwater. While little work has been done to quantify water relations of California sycamore in its native habitat, riparian species in general have high transpiration and little stomatal control, reflecting their high water supplies (as reviewed in Tabacchi et al. 2000). Thus, when planted in an arid urban environment where water is not limiting, yet VPD is high, they are predisposed to having high rates of water use. Despite being greater than normally observed for natural trees, the highest daily $J_{O}$ we measured for California sycamore were actually about $50 \%$ less than London planetrees measured in the semi-arid urban environment of Salt Lake City, Utah. This difference could reflect the difference in species, or the smaller size of trees in that study (Bush et al. 2008).

In contrast, Canary Island pine is native to a Mediterranean climate that is similar to Southern California but can have higher annual precipitation (Luis et al. 2005). Canary Island pine is found in areas ranging in precipitation from $200-1200 \mathrm{~mm}$ (Climent et al. 2002; Climent et al. 2004), indicating plasticity and tolerance of dry conditions. A study of this species in its native habitat (with annual precipitation $=638 \mathrm{~mm}$ ) found an annual transpiration of $252 \mathrm{~mm}$, which the authors suggested is below many other Mediterranean forest ecosystems (Luis et al. 2005). That study presented only relativized sapflux density values, so we are unable to directly compare our values; however, we can reasonably conclude that Canary Island pine is adapted to be conservative in its water use and has strong stomatal control of water loss, unlike California sycamore. Yet, when water is abundant (e.g. in the Irrigated site over much of the summer period), Canary Island pine can have similar $E$ to California sycamore (Fig. 7), due to the greater sapwood depth of Canary Island pine (Table 1).

\section{Climatic drivers of spatial variability in water use}

Daily $J_{O}$ of California sycamore during all time periods showed a very gradually saturating relationship with VPD (Fig. 3). Previous studies of the response of sapflux to VPD in diffuse porous species in natural forests showed saturation at much lower values of VPD than the present study (e.g. Oren and Pataki 2001; Pataki et al. 2000; Pataki and Oren 2003). However, in another study of urban diffuse porous trees in a semi-arid environment, sapflux increased nearly linearly in response to VPD (Bush et al. 2008). In that study, the authors suggested that diffuse porous species show lower stomatal control than ring porous species due to intrinsic differences in xylem anatomy that lead to differences in vulnerability to cavitation. In this study California sycamore showed evidence of some progressive cavitation during the course of the growing season, with a seasonal decline (at a given VPD) in $J_{O}$ (Fig. 3). This decline was observed both in the Natural site, as well as the urban Street trees site, although not in the urban Irrigated site. The Irrigated site generally experienced lower VPD than the other sites over most of the experimental period, which may have resulted in less cavitation and more seasonally constant $J_{O}$ (Fig. 3). 
Sapflux data for Canary Island pine suggested more conservative stomatal behavior that maintained constant $J_{O}$ over a large range of VPD (Fig. 4), except under very low soil moisture conditions. During conditions of low RWC, $J_{O}$ was only weakly related to VPD, but even under high RWC conditions, $J_{O}$ showed saturation at relatively low VPD. This response is somewhat contrary to a study of Canary Island pine in its native habitat. Luis et al. (2005) found that the response of relativized sapflux to increasing VPD was saturating only during the dry (summer) season, but was linearly related to VPD during the wet (winter) season. One reason for the difference between our results and the previous study may be that the maximum "wet" season VPD observed in our study was $\sim 1 \mathrm{kPa}$ greater than that observed in the native habitat study (Fig 4d; Luis et al. 2005). Furthermore, the pines in the Unirrigated site showed a much more drastic reduction in "dry" season water use than the pines measured in the Canary Islands, where wet and dry season transpiration were fairly comparable (Luis et al. 2005). This discrepancy may be due to a restriction of the normally deep-rooted pine (Luis et al. 2005) to shallow soil layers due to thin hillside soil (parent material observed at $<30 \mathrm{~cm}$ depth).

Many species show linear relationships of daily sapflux or transpiration to photosynthetically active radiation (e.g. Bovard et al. 2005; Ewers et al. 2005; Oren and Pataki 2001). As shade intolerant species, (USDA 2009; Climent et al. 2006) sapflux of California sycamore and Canary Island pine would be expected to respond to variations in PAR. This was the case for California sycamore at the Natural and Street tree sites but not at the Irrigated site. Conversely, in Canary Island pine, $J_{O}$ in the Irrigated site responded to PAR, but $J_{O}$ in the Unirrigated site did not. Lack of response in the Unirrigated site may be a function of the more restricted PAR range (once data with $\mathrm{RWC}<0.5$ was filtered out) at that site. The range in variability explained by PAR was similar for California sycamore $(0-$ $28 \%)$ and Canary Island pine (0-18\%; Table 3$)$.

Role of water stress in spatial variability of water use

Sapflux of California sycamore appeared to be largely unresponsive to shallow soil moisture. At the Irrigated site, frequent irrigation kept the soil moisture from dropping below $\mathrm{RWC}=0.5$ for nearly the entire measurement period. This may have also been the case at the Street trees site: although soil moisture data was not available, based on sapflux rates and leaf $\delta^{13} \mathrm{C}$ measurements, the trees appeared to have ample water. At the Natural site, where shallow soil moisture was very low $(\mathrm{RWC}<0.05)$ for the entire measurement period, significant variability in $J_{O}$ was attributed to RWC. However, given that California sycamore is an obligate riparian phreatophyte (Holstein 1984), these trees likely had access to groundwater, and the apparent response of $J_{O}$ to RWC may be attributable to seasonally changing groundwater levels, which were not directly measured.

In contrast to the weak response of California sycamore to shallow soil moisture, $J_{O}$ of Canary Island pine began declining around $\mathrm{RWC}=0.4$ at both the Irrigated and Unirrigated sites. While the shapes of the relationships of $J_{O}$ and RWC are somewhat different at the two sites, some of the difference may be related to the fact that $J_{O}$ at the Unirrigated site was too low to detect when RWC was below $\sim 0.2$. A study of the response of sapflux to soil moisture in Canary Island pine's native habitat also showed a decline in sapflux with declining soil moisture during the dry season (Luis et al. 2005). As mentioned previously, the very strong response of the pines in the Unirrigated site to declining shallow soil moisture could be due to the shallowness of the soil (parent material observed at depths $<30 \mathrm{~cm}$ ) preventing the establishment of deep roots. Despite apparent effects of seasonal water stress, Canary Island pine can grow in areas with precipitation as low as $200 \mathrm{~mm}$ (Climent et al. 
2002; Climent et al. 2004), has low transpiration in its native habitat (Luis et al. 2005), and is extremely resistant to cavitation (Fig. 6b). Therefore, Canary Island pine appears to tolerate very low soil moisture conditions with a combination of resistance to cavitation and stomatal closure. Overall, California sycamore showed few signs of water stress, and water availability did not appear to be a major factor explaining spatial variability in water use. As an obligate phreatophyte, California sycamore cannot be grown without ample water, and therefore comparisons of both species without access to groundwater or irrigation water are not possible. In other words, Canary Pine Island pine appears to be a more suitable species for dry urban habitats when water resources for irrigation are limited.

Other drivers of spatial variability in water use

To our knowledge, there have been no previous studies of site level spatial heterogeneity in urban tree transpiration. We evaluated spatial variability by accounting for variability driven by differences in meteorological conditions (VPD, PAR, RWC; Figs. 3, 4 and 5). We then wished to correlate the remaining variability with other parameters such as nutrient availability and differences in hydraulic architecture among sites.

One of the most unexpected findings was that the Street trees had the highest rates of $J_{O}$ and $E$ among California sycamore sites, after accounting for differences in climatic conditions. In fact, during the mid and late summer periods, $J_{O}$ and $E$ at the Street tree site were nearly double that at the other two sites (Fig. 3, 7a). The Street trees site was the most managed/human impacted of all the sites: trees grow next to pavement, in planting strips with limited infiltration surface, and likely experience atmospheric pollution (trees are immediately adjacent to a street and a thick layer of particulates was observed on leaves throughout the season). Thus, high $J_{O}$ and $E$ occurred despite a seemingly suboptimal growth environment. One factor to consider is that increased rates of water loss can result from ozone damage (as reviewed by Darrall 1989; Paoletti and Grulke 2005). However, there was no evidence of stomatal damage, considering that the response of $J_{O}$ to increasing VPD was similar across all sites (Fig. 3, Table 2), and nighttime sapflux was not evident on nights without elevated VPD (not shown). However, there did appear to be greater nutrient availability at the Street tree site, which showed the highest organic and inorganic soil $\mathrm{N}$ concentrations (Table 4), possibly due to fertilizer runoff from nearby lawns. This site also exhibited a different soil $\delta^{15} \mathrm{~N}$ (Table 4), which may indicate an enriched source from pollution, or perhaps high rates of nitrification, denitrication, and volatization that enriches the remaining soil N (Amundson et al. 2003; Högberg 1990; Robinson 2001). Leaf $\delta^{13} \mathrm{C}$ was also very depleted at this site (Table 4), which may indicate high stomatal conductance or alternatively a large influence of fossil fuel derived atmospheric $\mathrm{CO}_{2}$. However, leaf $\% \mathrm{~N}$ and $\mathrm{C} / \mathrm{N}$ did not show high leaf $\mathrm{N}$ concentrations at the Street Tree site (Table 4). Notably, we were not able to quantify leaf area in this study, which may play a large role in influencing sapflux and transpiration rates. We suggest that high nutrient availability deriving from atmospheric pollution or fertilizer runoff is a likely explanation for high rates of sapflux, either through effects of nutrients on photosynthetic rates and subsequently stomatal conductance or more likely (given leaf $\mathrm{N}$ concentrations) on leaf area. From our measurements of xylem hydraulic properties, differences in sapflux rates were clearly not mediated by differences in stem hydraulic conductivity or vulnerability to cavitation (Fig. 6), which did not vary among sites.

Site differences in water use of Canary Island pine appear to have been driven largely by soil water availability. During the final period of the study, when both the Irrigated and Unirrigated sites had similar (mostly high) RWC and PAR, the responses of $J_{O}$ to VPD was identical 
(Fig. 4d). Leaf $\delta^{13} \mathrm{C}$ was consistent with the differential water availability in the two sites, with greater enrichment at the Unirrigated site (Table 4), although again, we cannot distinguish between the effects of physiology and fossil fuel dilution with these measurements. Contrary to the expectation that low water availability might result in a lower hydraulic conductivity and lower vulnerability to cavitation at the Unirrigated site, vulnerability was the same at both sites (Fig. 6b) and $K$ was actually higher in the Unirrigated site (Fig. 7d).

California sycamore is widely planted in southern California cities because it is one of the few tree species native to low elevations. While there is a common assumption that native species require less management, our results show that native species in dry environments don't always use less water than non-native species: the obligate-riparian yet native California sycamore had much higher $J_{O}$ than the non-native Canary Island pine, which is adapted to dry habitats. As a phreatophyte that needs access to deep soil moisture and groundwater, California sycamore showed little evidence of responses to shallow soil moisture, although there was a seasonal decline in $J_{O}$ that may have been caused by progressive cavitation in response to high VPD. In contrast, $J_{O}$ of Canary Island pine was sensitive to shallow soil moisture conditions, but tolerant of very low soil moisture. Thus, although $E$ was similar for the two species where water was abundant, Canary Island pine can grow in locations without significant irrigation or groundwater access, whereas California sycamore cannot. Heterogeneity in resource availability within the urban environment contributed to significant differences in water use of the same species growing in different locations, but did not affect hydraulic conductivity and vulnerability to cavitation within species. The highest rates of $J_{O}$ in this study were found in California sycamore trees grown in planting strips in a Los Angeles street. There was evidence of high nutrient availability at this site, caused by atmospheric pollution or fertilizer runoff, which may have caused an increase in photosynthesis, stomatal conductance, and/or leaf area. Thus, our results show that urban trees, even highly impacted street trees, can perform quite well physiologically and show few signs of stress. A limitation to this study and other studies of urban trees is that the allometry of urban trees is highly uncertain, and additional information about urban tree root area, leaf area, and root:shoot ratios will be very beneficial in improving our understanding of plant water relations in urban environments. This study adds to a growing body of knowledge about the role of plant processes in the urban environment and the controls on urban plant ecophysiology.

Acknowledgements We would like to thank Stephanie Pincetl, Sandy and Pete DeSimone (Starr Ranch Sanctuary), University of California-Irvine Facilities Management, and Cathleen Cox and DJ Smetana (Los Angeles Zoo and Botanical Gardens) for permission to conduct research on their property. We would also like to thank Anait Arsenyan, Melissa Benitz, Neeta Bijoor, Christine Goedhart, Sonja Djuricin, Liza Litvak, Amy Townsend-Small, and Dachun Zhang for assistance in the laboratory and the field. This study was supported by the National Science Foundation (HSD 0624342) and the Environmental Protection Agency (RD-83336401-0).

Open Access This article is distributed under the terms of the Creative Commons Attribution Noncommercial License which permits any noncommercial use, distribution, and reproduction in any medium, provided the original author(s) and source are credited.

\section{References}

Akbari H (2002) Shade trees reduce building energy use and $\mathrm{CO}_{2}$ emissions from power plants. Environ Pollut 116:S119-S216 
Alder NN, Sperry JS, Pockman WT (1996) Root and stem xylem embolism, stomatal conductance, and leaf turgor in Acer grandidentatum populations along a soil moisture gradient. Oecologia 105:293-301

Alder NN, Pockman WT, Sperry JS, Nuismer S (1997) Use of centrifugal force in the study of xylem cavitation. J Exp Bot 48:665-674

Amundson R, Austin AT, Schuur EAG, Yoo K, Matzek V, Kendall C, Uebersax A, Brenner D, Baisden WT (2003) Global patterns of the isotopic composition of soil and plant nitrogen. Glob Biogeochem Cycles 17:1031. doi:10.1029/2002GB001903

Balling RC, Gober P, Jones N (2008) Sensitivity of residential water consumption to variations in climate: an intraurban analysis of Phoenix, Arizona. Water Resour Res 44:doi:10.1029/2007WR006722

Bovard BD, Curtis PS, Vogel CS, Su H-B, Schmid HP (2005) Environmental controls on sap flow in a northern hardwood forest. Tree Physiol 25:31-38

Bush SE, Pataki DE, Hultine KR, West AG, Sperry JS, Ehleringer JR (2008) Woody anatomy constrains stomatal responses to atmospheric vapor pressure deficit in irrigated, urban trees. Oecologia 156:13-20

Cadenasso ML, Pickett STA, Schwarz K (2007) Spatial heterogeneity in urban ecosystems: reconceptualizing land cover and a framework for classification. Front Ecol Environ 5:80-88

Clark JR, Kjelgren RK (1990) Water as a limiting factor in the development of urban trees. J Arboric 16:203-208

Climent J, Chambel MR, Pérez E, Gil L, Pardos JA (2002) Relationship between heartwood radius and early radial growth, tree age, and climate in Pinus canariensis. Can J For Res 32:103-111

Climent J, Tapias R, Pardos JA, Gil L (2004) Fire adaptations in the Canary Islands pine (Pinus canariensis). Plant Ecol 171:185-196

Climent JM, Aranda I, Alonso J, Pardos JA, Gil L (2006) Developmental constraints limit the response of Canary Island pine seedlings to combined shade and drought. For Ecol Manag 231:164-168

Close RE, Kielbaso JJ, Nguyen PV, Schutzki RE (1996a) Urban vs. natural sugar maple growth II. Water relations. J Arboric 22:187-192

Close RE, Nguyen PV, Kielbaso JJ (1996b) Urban vs. natural sugar maple growth: stress symptoms and phenology in relation to site characteristics. J Arboric 22:144-150

Darrall NM (1989) The effect of air pollutants on physiological processes in plants. Plant Cell Environ 12:130

Ewers BE, Oren R, Sperry JS (2000) Influence of nutrient versus water supply on hydraulic architecture and water balance in Pinus taeda. Plant Cell Environ 23:1055-1066

Ewers BE, Gower ST, Bond-Lamberty B, Wang CK (2005) Effects of stand age and tree species on canopy transpiration and average stomatal conductance of boreal forests. Plant Cell Environ 28:660-678

Ford CR, Goranson CE, Mitchel RJ, Will RE, Teskey RO (2004a) Diurnal and seasonal variability in the radial distribution of sap flow: predicting total stem flow in Pinus taeda trees. Tree Physiol 24:951-960

Ford CR, McGuire MA, Mitchell RJ, Teskey RO (2004b) Assessing variation in the radial profile of sap flux density in Pinus species and its effect on daily water use. Tree Physiol 24:241-249

Gebauer T, Horna V, Leuschner C (2008) Variability in radial sap flux density patterns and sapwood area among seven co-occuring temperature broad-leaved tree species. Tree Physiol 28:1821-1830

Gleick PH, Haasz D, Henges-Jeck C, Srinivasan V, Wolff G, Kao Cushing K, Mann A (2003) Waste not, want not: the potential for urban water conservation in California. Pacific Institute, Oakland

Granier A (1987) Evaluation of transpiration in a Douglas-fir stand by means of sap flow measurements. Tree Physiol 3:309-320

Grimm N, Grove J, Pickett S, Redman C (2000) Integrated approaches to long-term studies of urban ecological systems. Bioscience 50:571-584

Grimmond CSB, Souch C, Hubble MD (1996) Influence of tree cover on summertime surface energy balance fluxes, San Gabriel Valley, Los Angeles. Clim Res 6:45-57

Hickman JC (1993) The Jepson manual: higher plants of California. University of California Press, Berkeley

Högberg P (1990) Forests losing large quantities of nitrogen have elevated ${ }^{15} \mathrm{~N}:{ }^{14} \mathrm{~N}$ ratios. Oecologia $84: 229-231$

Holstein G (1984) California riparian forests. In: Warner RE, Hendrix KM (eds) California riparian systems: ecology, conservation, and productive management. University of California Press, Berkeley, pp 3-23

Jones MN (1984) Nitrate reduction by shaking with cadmium: alternative to cadmium columns. Water Res 18:643-646

Kjelgren RK, Clark JR (1993) Growth and water relations of Liquidambar styraciflua L. in an urban park and plaza. Trees 7:195-201

Ladjal M, Huc R, Ducrey M (2005) Drought effects on hydraulic conductivity and xylem vulnerability to embolism in diverse species and provenances of Mediterranean cedars. Tree Physiol 25:1109-1117

Luis VC, Jimenez MS, Morales D, Kucera J, Wieser G (2005) Canopy transpiration of a Canary Islands pine forest. Agric For Meteorol 135:117-123 
McPherson EG, Simpson JR, Peper PJ, Maco SE, Xiao Q (2005) Municipal forest benefits and costs in five US cities. J For 103:411-416

Morris TR (2006) The climate of Los Angeles, California. National Weather Service, Los Angeles/Oxnard

Nadezhdina N, Cermak J, Ceulemans R (2002) Radial patterns of sap flow in woody stems of dominant and understory species: scaling errors with positioning of sensors. Tree Physiol 22:901-918

Nowak DJ, Crane DE (2000) The Urban Forest Effects (UFORE) model: quantifying urban forest structure and functions. In: Hansen M, Burk T (eds) Integrated tools for natural resources inventories in the 21st century GTR NC-212. U.S. Dept. of Agriculture, Forest Service, North Central Forest Experiment Station, pp 714-720

Nowak DJ, Dwyer JF (2007) Understanding the benefits and costs of urban forest ecosystems. In: Kuser J (ed) Urban and Community Forestry in the Northeast. Springer Science and Business Media, pp 25-46

Nowak DJ, Crane DE, Stevens JC, Hoehn RE, Walton JT, Bond J (2008) A ground-based method of assessing urban forest structure and ecosystem services. Arboric Urban For 34:347-358

Oren R, Pataki DE (2001) Transpiration in response to variation in microclimate and soil moisture in southeastern deciduous forests. Oecologia 127:549-559

Paoletti E, Grulke NE (2005) Does living in elevated $\mathrm{CO}_{2}$ ameliorate tree response to ozone? A review of stomatal responses. Environ Pollut 137:483-493

Pataki DE, Oren R (2003) Species differences in stomatal control of water loss at the canopy scale in a mature bottomland deciduous forest. Adv Water Resour 26:1267-1278

Pataki DE, Oren R, Smith WK (2000) Sap flux of co-occurring species in a western subalpine forest during seasonal soil drought. Ecology 81:2557-2566

Pataki DE, Alig RJ, Fung AS, Golubiewski NE, Kennedy CA, McPherson EG, Nowak DJ, Pouyat RV, Romero Lankao P (2006) Urban ecosystems and the North American carbon cycle. Global Change Biol 12:2092-2101

Perakis SS, Hedin LO (2001) Fluxes and fates of nitrogen in soil of an unpolluted old-growth temperate forest, Southern Chile. Ecology 82:2245-2260

Phillips N, Oren R, Zimmermann R (1996) Radial trends in xylem sap flow in non-, diffuse- and ring-porous species. Plant Cell Environ 19:983-990

Pickett STA, Cadenasso ML (2009) Altered resources, disturbance, and heterogeneity: A framework for comparing urban and non-urban soils. Urban Ecosyst 12:23-44

Pickett STA, Cadenasso ML, Grove JM, Nilon CH, Pouyat RV, Zipperer WC, Costanza R (2001) Urban ecological systems: linking terrestrial ecological, physical, and socioeconomic components of metropolitan areas. Annu Rev Ecol Syst 32:127-157

Rhoades RW, Stipes RJ (1999) Growth of trees on the Virginia Tech campus in response to various factors. J Arboric 25:211-217

Robinson D (2001) $\delta^{15} \mathrm{~N}$ as an integrator of the nitrogen cycle. Trends Ecol Evol 16:153-162

Saveyn A, Steppe K, Lemeur R (2008) Spatial variability of xylem sap flow in mature beech (Fagus sylvatica) and its diurnal dynamics in relation to microclimate. Botany $86: 1440-1448$

Sperry JS, Donnelly JR, Tyree MT (1988) A method for measuring hydraulic conductivity and embolism in xylem. Plant Cell Environ 11:35-40

Tabacchi E, Lambs L, Guilloy H, Planty-Tabacchi AM, Muller E, Décamps H (2000) Impacts of riparian vegetation on hydrological processes. Hydrol Process 14:2959-2976

United States Department of Agriculture (2009) The PLANTS Database. National Plant Data Center, Baton Rouge, LA 70874-4490 USA. http://plants.usda.gov. Accessed 8 April 2009

Wang J, Endreny TA, Nowak DJ (2008) Mechanistic simulation of tree effects in an urban water balance model. J Am Water Resour Assn 44:75-85

White R, Havlak R, Nations J, Pannkuk T, Thomas J, Chalmers D, Dewey D (2007) How much water is "enough"? Using PET to develop water budgets for residential landscapes. Texas Water Resources Institute, Texas A\&M University, College Station

Whitlow TH, Bassuk NL (1987) Trees in difficult sites. J Arboric 13:10-17 